Gastroenterology. 2010 October ; 139(4): 1076-1080.e2. doi:10.1053/j.gastro.2010.08.012.

\title{
Hereditary Pancreatic Cancer
}

\author{
Shilpa Grover, M.D., M.P.H. ${ }^{1,2,3,4}$ and Sapna Syngal, M.D., M.P.H. ${ }^{1,2,3}$ \\ ${ }^{1}$ Department of Gastroenterology, Brigham and Women's Hospital Boston, MA \\ ${ }^{2}$ Population Sciences, Dana-Farber Cancer Institute, Boston, MA \\ ${ }^{3}$ Harvard Medical School, Boston, MA \\ ${ }^{4}$ Program in Cancer Outcomes Research Training, Massachusetts General Hospital, Boston, MA
}

\section{Introduction}

Pancreatic adenocarcinoma is the fourth leading cause of cancer death with an estimated 43,000 new diagnoses and 36,800 deaths annually. ${ }^{1}$ The low 5-year overall survival rate of patients with pancreatic adenocarcinoma of $6 \%$ is attributable to the largely characteristically late stage of pancreatic cancer at the time of diagnosis. ${ }^{2}$ Although most cases of pancreatic adenocarcinomas are thought to be sporadic, up to $10 \%$ may be due to an underlying genetic predisposition. ${ }^{3-4}$ This article reviews the epidemiology and genetic basis of hereditary pancreatic cancer and the emerging strategies for detection of early pancreatic neoplasms in high-risk individuals.

\section{Epidemiology}

Family history was recognized as a risk factor for pancreatic cancer as early as 1967 when pancreatic cancer was reported in an adenocarcinoma-prone family by Henry Lynch. ${ }^{5}$ In 1973, MacDermott and Kramer described a family in which four of six siblings were diagnosed with pancreatic cancer, and since then, other cases have been reported. ${ }^{6-11}$

A population-based case-control study conducted in Canada noted that $7.8 \%$ of patients with pancreatic cancer and $0.6 \%$ of controls had a family history of pancreatic cancer. ${ }^{12}$ This difference could not be explained by differences in environmental exposures. Another population-based, case control study conducted in the United States found that individuals with a first-degree relative (FDR) with pancreatic cancer had a 3.2-fold increased risk of developing pancreatic cancer (95\% CI 1.8-5.6) as compared to population controls. ${ }^{13}$

Prospective cohort studies have also demonstrated an increased risk of pancreatic cancer among individuals with a family history of pancreatic cancer. ${ }^{14-15}$ Coughlin et al. reported a 1.5 -fold increased risk of fatal pancreatic cancer in males with a family history of pancreatic cancer (multivariate relative risk [RR] 1.5, 95\% CI 1.1-2.1). ${ }^{14}$ In another population-based cohort study, Hemminki et al. also demonstrated an increased risk of pancreatic adenocarcinoma in an individual with a parent with pancreatic cancer (standardized incidence ratio $1.73,95 \%$ CI 1.1-2.5). ${ }^{15}$ These findings have prompted further studies to determine if the clustering of pancreatic cancer is attributable to a shared underlying genetic basis and/or due to environmental factors.

Corresponding Author: Sapna Syngal, M.D., M.P.H., Associate Professor of Medicine, Dana-Farber Cancer Institute, 44 Binney Street, Smith 209, Boston, MA 02114, Tel: (617) 632-5022, Fax: (617) 632-4088, ssyngal@partners.org.

Disclosures:

Dr. Grover has no disclosures, Dr. Syngal serves as a consultant to Archimedes Inc. and Cequent Inc. 


\section{Genetic Basis}

Inherited gene mutations as seen in hereditary pancreatitis and with inherited cancer syndromes including hereditary breast and ovarian cancer syndrome, Peutz-Jeghers syndrome, Lynch syndrome, and familial atypical multiple mole melanoma contribute to the familial aggregation of pancreatic cancers. However, such "hereditary pancreatic cancer" cases in which pancreatic cancers are due to a known genetic defect account for a small fraction of clustering of pancreatic cancer cases.

"Familial pancreatic cancer" (FPC) has been used to describe families with at least 2 firstdegree relatives (FDR) with pancreatic cancer without a known genetic defect. Complex segregation analysis suggests that the aggregation of pancreatic cancer in these families is due to an unidentified, autosomal dominantly inherited gene with reduced penetrance. ${ }^{16}$ Although initial linkage studies suggested that the palladin gene (PALD) may be a predisposition gene for pancreatic cancer ${ }^{17}$ these findings have not been validated. ${ }^{18-21}$ Studies of FPC kindreds suggest that germline BRCA2 mutations may be found in 17-19\% of tested kindreds with an incident pancreatic cancer. ${ }^{22-23}$

To evaluate the risk of pancreatic cancer in families with pancreatic cancer, Klein et al. conducted a prospective study of 838 kindreds in the National Familial Pancreas Tumor Registry (NFPTR). Standardized incidence ratios were derived by comparing the number of incident pancreatic cancers cases with those expected using Surveillance, Epidemiology and End Results rates. Among individuals from FPC kindreds, individuals with three or more affected FDRs with pancreatic cancer had a 32.0-fold increased risk of developing pancreatic cancer (95\% CI 10.4-74.7). Those with two affected FDRs had a 6.4-fold increased risk (95\% CI 1.8-16.4), and those with one affected FDR had a 4.5-fold increased risk (95\% CI 0.54-16.3). ${ }^{24}$ The complexity in cancer risk assessment has led to the development of a risk prediction model (PancPRO) to provide more detailed risk estimates for individuals from FPC kindreds that take into account the ages at cancer diagnosis, family size, and the relationship between family members. ${ }^{25}$

\section{Pancreatic Cancer Associated with Inherited Cancer Syndromes}

\section{Peutz-Jeghers Syndrome}

Peutz-Jeghers syndrome (PJS) is an autosomal dominant hamartomatous polyposis syndrome with high penetrance. The estimated frequency of PJS is $1 / 8,300-1 / 280,000$ individuals. Individuals with PJS have distinctive mucocutaneous pigmentation with multiple pigmented macules on the lips, buccal mucosa, periorbital areas as well as the forearms, palms, soles, fingers and perianal area. Macules on the skin manifest in early life and tend to progress but perioral lesions may fade with age. Individuals with PJS develop hamartomatous polyps throughout the gastrointestinal tract. A clinical diagnosis of PJS can be made in individuals who have two or more of the following criteria: (i) two or more Peutz-Jeghers polyps of the small bowel, (ii) characteristic mucocutaneous pigmentation, (iii) family history of PJS.

PJS is caused by inherited mutations in the STK11/LKB1 gene located at 19p13.3. STK11 encodes a novel serine/threonine kinase that is thought to function as a tumor suppressor. Mutations in STK11 are detected in 80-94\% of individuals who meet diagnostic criteria. ${ }^{26-27}$ Colorectal cancer (CRC) is the most frequent gastrointestinal malignancy $(39 \%){ }^{28-29}$ The estimated lifetime risk of pancreatic cancer in individuals with PJS is 11$36 \%{ }^{28-29}$ Other gastrointestinal cancers include gastric (29\%), and small bowel adenocarcinomas (13\%). Individuals with PJS are also at risk for breast cancer (32-54\%) 
and gynecologic malignancies including ovarian sex cord tumors (21\%), endometrial cancer $(9 \%)$, adenoma malignum of the cervix $(10 \%)$ and testicular cancer $(9 \%)$ in men. ${ }^{28}$

\section{Familial Atypical Multiple Mole Melanoma}

Familial atypical multiple mole melanoma (FAMMM) is an autosomal dominantly inherited syndrome with incomplete penetrance. Germline mutations $16 / C D K N 2 A$ gene are associated with FAMMM although there has been wide variability in the reported prevalence of $C D K N 2 A$ mutations in patients with FAMMM ${ }^{30-34}$ FAMMM is characterized by the presence of multiple melanocytic nevi and atypical melanocytic nevi, and an increased risk of malignant melanoma. ${ }^{35-36}$ In addition to pancreatic cancer, individuals with FAMMM are also at increased risk of developing sarcomas and cancers of the lung and breast. ${ }^{37-38}$ The risk of pancreatic cancer in kindreds with FAMMM is 13-22 fold higher than the average population 37,39 and individuals with a germline $p 16$ mutation have a 38 -fold higher risk of pancreatic cancer than the general population. ${ }^{40}$ This elevated cancer risk highlights the significance of genetic counseling for early identification of individuals at risk for FAMMM. ${ }^{41}$

\section{Lynch Syndrome}

Lynch syndrome, the most common inherited familial colorectal cancer syndrome, results from a mutation in one of the mismatch repair genes MLH1, MSH2, MSH6 and PMS2. Lynch syndrome is characterized by early onset of CRC and a predisposition to cancers of the endometrium, ovary, stomach, small bowel, urinary tract and brain. Although pancreatobiliary tumors have long been included in the spectrum of Lynch syndrome associated malignancies, the magnitude of the risk of pancreatic cancer has only recently been quantified. It is estimated that the cumulative risk of pancreatic cancer in individuals with Lynch syndrome is 3.7\% up to age 70 which represents an 8.6-fold increase compared to the general population. ${ }^{42}$ Pancreatic cancers in individuals with Lynch syndrome frequently have a characteristic medullary appearance. ${ }^{43-44}$ These tumors are poorly differentiated and demonstrate prominent lymphocytic infiltration. In addition they demonstrate loss of protein expression of mismatch repair genes and are associated with microsatellite instability (MSI). ${ }^{44-45}$ It may therefore be reasonable to perform tumor MSI testing in patients with a family history suggestive of Lynch syndrome or the presence of young onset medullary cancer of the pancreas.

\section{Hereditary Breast and Ovarian Cancer Syndrome}

Hereditary breast and ovarian cancer syndrome (HBOC), an autosomal dominantly inherited syndrome is characterized by early-onset breast and/or ovarian cancers. Germline mutations in BRCA1 and BRCA2 genes are responsible for the breast and ovarian cancer syndrome in most families. ${ }^{46}$ BRCA proteins are involved in transcriptional regulation of gene expression and recognition and repair of DNA damage.

It is unclear if $B R C A 1$ mutations are associated with an increased risk of adenocarcinoma of the pancreas. Large studies of $B R C A 1$ mutation positive families, ascertained for young onset of breast and/or ovarian cancers, suggested that the risk for pancreatic cancer is 2-3 fold higher in $B R C A l$ carriers than the general population. ${ }^{47-48}$ However, in other studies $B R C A 1$ mutations appear to be rare in families with pancreatic cancer that do not have a significant history of breast cancer. ${ }^{49}$

Germline BRCA2 mutations have been clearly associated with an increased risk of pancreatic cancer with a RR $3.51(1.87-6.58) .{ }^{50}$ A number of studies have evaluated the prevalence of $B R C A$ mutations in patients with pancreatic cancer. In patients with pancreatic cancer and 2 or more FDRs with pancreatic cancer the prevalence of $B R C A 2$ mutations has 
been estimated to range from $17-19 \% .^{22-23,51}$ In another study, of patients with apparently sporadic pancreatic cancer, Goggins et al. demonstrated that $7.3 \%$ had germline BRCA2 mutations. ${ }^{52}$ It has been established that $1.1 \%$ of the Jewish population carries a BRCAl founder mutation and $1.1 \%$ carries a $B R C A 2$ founder mutation. Studies evaluating the prevalence of founder mutations have found that $5.5-10 \%$ of Ashkenazi Jewish patients with pancreatic cancer have $B R C A 2$ founder mutations. ${ }^{53-57}$ Given these findings, it may therefore be reasonable to consider testing for $B R C A$ founder mutations in Ashkenazi Jewish patients with pancreatic cancer even in the absence of a family history suggestive of HBOC.

\section{Hereditary Pancreatitis}

Hereditary pancreatitis is a rare inherited form of chronic pancreatitis characterized by recurrent attacks of acute pancreatitis in childhood or early adolescence. Chronic pancreatitis develops in late adolescence or early adulthood. These individuals have an increased risk for pancreatic cancer beginning in the fifth decade of life. The largest proportion of hereditary pancreatitis is caused by germline mutations in PRSSI on chromosome 7q35. Germline mutations in the PRSS1 gene, which encodes cationic trypsinogen, has been associated with an autosomal dominant form of hereditary pancreatitis. Multiple mutation sites have been identified, the two most common of which are $\mathrm{R} 122 \mathrm{H}$ and N29I ${ }^{58}$ Some mutations in PRSS1 result in premature trypsin activation or ineffective deactivation of trypsin by eliminating a trypsin autodegradation site both of which result in pancreatic parenchymal injury. ${ }^{58-60}$

Although hereditary pancreatitis accounts for a small percentage of pancreatic cancer cases, it is associated with a markedly elevated risk of pancreatic cancer (lifetime risk 25$40 \%) .{ }^{61,62}$ Smoking not only increases the risk of pancreatic cancer approximately two-fold in patients with hereditary pancreatitis, but smokers develop pancreatic cancer 20 years earlier than nonsmokers. ${ }^{63}$

\section{Screening for Pancreatic Cancer}

Surgical resection is the only potentially curative treatment for pancreatic cancer; however only $15-20 \%$ of patients are candidates for pancreatectomy at the time of diagnosis. The 5year survival following pancreaticoduodenectomy, although low (25-30\% in node-negative patients and $10 \%$ in node-positive patients), is significantly higher than in those with unresectable disease. In one study, Japanese investigators reported a 4-year survival of $78 \%$ of patients who had undergone resection of a small stage I ductal adenocarcinoma less than $2 \mathrm{~cm} .^{2}$ Although there is no consensus regarding the extent of surgical resection in individuals identified with high-grade precursor lesions, it is hoped that early surgical resection can significantly improve survival.

Routine screening for pancreatic cancer is of limited utility in average risk individuals given the low incidence of pancreatic cancer and the lack of a low cost, noninvasive, diagnostic test with high sensitivity and specificity. However, certain high-risk subgroups including individuals with FPC and inherited cancer syndromes that have a significantly elevated lifetime risk of pancreatic cancer may benefit from screening with the aim to detect early pancreatic lesions that can be intervened upon.

Two such precursor lesions of pancreatic cancer include intraductal papillary mucinous neoplasms (IPMN) and pancreatic intraepithelial neoplasia (PanIN). ${ }^{64}$ Both have been well characterized and may potentially serve as targets for early intervention. IPMNs are grossly visible mucin producing epithelial neoplasms arising from the main or branch pancreatic ducts. PanIN lesions are microscopic non-invasive neoplasms involving ducts less than 5-10 $\mathrm{mm}$ and are characterized by columnar to cuboidal cells with varying degree of atypia. 
Indeed, a model for histologic and genetic progression from normal cells to PanIN lesions to invasive pancreatic cancer has been developed. ${ }^{65-66}$

\section{Evidence for Screening}

Screening studies in high-risk cohorts have demonstrated that early pre-invasive pancreatic lesions in the pancreas can be detected in at-risk persons, who could then be treated before the development of an invasive cancer. ${ }^{67}$ In a prospective cohort study, 14 patients from 3 kindreds with FPC underwent both endoscopic ultrasound (EUS) and endoscopic retrograde cholangiopancreatogram (ERCP) ${ }^{67}$ Although no pancreatic cancers were found, all 7 individuals with abnormalities on EUS and ERCP were found to have widespread PanIN lesions on pancreatectomy.

In a pilot study to evaluate the feasibility of screening at-risk relatives with pancreatic cancer in FPC kindreds, Canto et al. screened 38 asymptomatic subjects with EUS. The diagnostic yield for detecting clinically significant pancreatic neoplasms was $5.3 \% .^{68}$ In a subsequent prospective, single-center, case control study; the same group found that screening with EUS and CT diagnosed a significant number of asymptomatic pancreatic neoplasms in high-risk individuals. In this study, 78 high-risk patients ( 72 from FPC kindreds with $\geq 3$ affected members, 6 PJS) and 149 control patients were screened at baseline and 12-months with both EUS and pancreatic protocol CT. Pancreatic neoplasia were confirmed in 8 patients (10\% yield): 6 patients had 8 benign IPMNs with diffuse multifocal PanIN lesions, 1 had an IPMN that progressed to invasive ductal adenocarcinoma, and 1 had high grade PanIN. ${ }^{69}$ It is important to note that approximately half of the pre-malignant or malignant lesions were found at the time of surgery and not during screening. ${ }^{70-71}$

However, the yield of screening has not been uniformly high. A recent 5-year prospective screening study of 76 asymptomatic individuals at risk for pancreatic cancer who underwent annual EUS and magnetic resonance imaging (MRI) /magnetic resonance cholangiopancreatogram (MRCP)/magnetic resonance angiography (MRA), reported finding only 1 significant IPMN corresponding to a yield of $1.3 \%$. It is important to note that although this study included high-risk individuals ( $\geq 3$ relatives with pancreatic cancer and known BRCA2 mutation carriers), 57\% of the cohort comprised of individuals with 2 or more FDRs with pancreatic cancer who are considered to be at moderate risk (5-10 fold increased risk). Also in contrast to other screening studies, the uptake of screening was markedly lower and outcomes of those patients are unknown. ${ }^{72}$

\section{Screening Modalities}

Although the optimal approach for screening for early pancreatic neoplasia is still in question, studies suggest that computed tomography (CT) has the lowest sensitivity for pancreatic neoplasms. ${ }^{68-69}$ Other disadvantages include radiation exposure and the inability to image non-dilated pancreatic ducts. ERCP, the gold standard for imaging the pancreatic duct is not the test of choice for screening due to the risk of pancreatitis.

EUS combines endoscopy with high frequency ultrasound thereby avoiding exposure to radiation. Studies have demonstrated that EUS has a higher sensitivity as compared to CT in detecting pancreatic cancer. ${ }^{73}$ EUS has a high positive predictive value for PanIN in highrisk individuals. ${ }^{67}$ EUS can also accurately detect IPMNs and has the advantage of being able to visualize mural nodules, a feature associated with an increased risk of malignancy. ${ }^{74-75}$ Chronic pancreatitis seen on EUS in individuals with FPC has been associated with lobulocentric atrophy and may be a marker of multifocal PanIN lesions. ${ }^{76}$ 
Limitations of EUS include high inter-observer variability, high cost and complications associated with endoscopy.

MRI/MRCP provides a non-invasive method for screening high-risk individuals while avoiding the risk of radiation exposure and pancreatitis. Recent studies report equal or greater accuracy for MRI/MRCP compared to $\mathrm{CT}^{77}$ and $\mathrm{ERCP}{ }^{78}$ in the diagnosis of IPMNs. Furthermore, secretin-enhanced MRCP may improve the sensitivity for small ductal lesions by increasing pancreatic secretion. ${ }^{79}$

\title{
Recommendations for Screening
}

A consensus conference proposed that screening for pancreatic cancer be performed only as part of a peer-reviewed protocol. It was suggested that pancreatic cancer screening be considered in individuals with $>10$-fold increased risk of pancreatic cancer. ${ }^{80}$ (Table 3 ) Although there are no clear guidelines as to when to start screening, expert recommendations are based on the mean age of pancreatic cancer and the youngest age of onset of pancreatic cancer in the family. In individuals with FPC the mean age of onset is in the sixth decade of life. We recommend that pancreatic cancer screening be considered at the age of 40-45 years or 10-15 years younger than the youngest relative with pancreatic cancer. In patients with PJS screening for pancreatic cancer is recommended at age 30 years. Since smoking has been shown to be an independent risk factor for pancreatic cancer in families with FPC, all high-risk individuals should be strongly counseled against smoking. ${ }^{81}$ In individuals with hereditary pancreatitis, in addition to smoking cessation a low-fat diet should also be recommended.

\section{Summary and Future Directions}

There have been significant advances in our understanding of hereditary pancreatic cancer over the past decade. At the present time, there are known inherited gastrointestinal cancer syndromes that predispose to pancreatic cancer; however, the genetic basis for FPC remains largely unidentified. The critical role of PanIN lesions as precursors of pancreatic cancer has become clear. It will be important to determine the natural history of untreated PanIN lesions and determine both the proportion and rate of progression to invasive carcinoma. Advances in proteomic analysis of PanIN lesions may allow us to reliably and accurately target early lesions for chemoprevention and more advanced lesions for early resection. ${ }^{82}$ With regard to screening, numerous studies have demonstrated that with current pancreatic cancer imaging modalities (EUS and MRI/MRCP), pancreatic precursor lesions are detectable and have a significant yield in appropriately selected, high-risk individuals. The optimal approach and frequency of screening has yet to be established. It also remains to be determined if pancreatic cancer screening in high-risk individuals decreases cancer incidence and improves survival. As these questions are answered, it remains essential that physicians perform a complete assessment of family cancer history in order to identify these high-risk individuals, who may benefit from genetic evaluation in addition to close monitoring.

\section{Acknowledgments}

\author{
Grant Support: \\ Dr. Grover: R25 CA 092203, Dr. Syngal: K24 CA113433-05, R01CA97075-07
}

\section{References}

1. American Cancer Society. Cancer Facts and Figures 2010. Available at http://www.cancer.org/ docroot/STT/content/STT_1x_Cancer_Facts_Figures_2010.asp. 
2. Furukawa H, Okada S, Saisho H, et al. Clinicopathologic features of small pancreatic adenocarcinoma. A collective study. Cancer. 1996 Sep 1; 78(5):986-990. [PubMed: 8780535]

3. Lynch HT, Smyrk T, Kern SE, et al. Familial pancreatic cancer: a review. Semin Oncol. 1996 Apr; 23(2):251-275. [PubMed: 8623061]

4. Brand RE, Lynch HT. Hereditary pancreatic adenocarcinoma. A clinical perspective. Med Clin North Am. 2000 May; 84(3):665-675. [PubMed: 10872423]

5. Lynch HT, Krush AJ, Larsen AL. Heredity and multiple primary malignant neoplasms: six cancer families. Am J Med Sci. 1967 Sep; 254(3):322-329. [PubMed: 6054534]

6. MacDermott RP, Kramer P. Adenocarcinoma of the pancreas in four siblings. Gastroenterology. 1973 Jul; 65(1):137-139. [PubMed: 4720820]

7. Ehrenthal D, Haeger L, Griffin T, Compton C. Familial pancreatic adenocarcinoma in three generations. A case report and a review of the literature. Cancer. 1987 May 1; 59(9):1661-1664. [PubMed: 3828965]

8. Reimer RR, Fraumeni JF Jr, Ozols RF, Bender R. Pancreatic cancer in father and son. Lancet. 1977 Apr 23.1(8017):911. [PubMed: 67325]

9. Friedman JM, Fialkow PJ. Carcinoma of the pancreas in four brothers. Birth Defects Orig Artic Ser. 1976; 12(1):145-150. [PubMed: 186135]

10. Dat NM, Sontag SJ. Pancreatic carcinoma in brothers. Ann Intern Med. 1982 Aug.97(2):282. [PubMed: 7103290]

11. Katkhouda N, Mouiel J. Pancreatic cancer in mother and daughter. Lancet. 1986 Sep 27.2(8509): 747. [PubMed: 2876211]

12. Ghadirian P, Boyle P, Simard A, Baillargeon J, Maisonneuve P, Perret C. Reported family aggregation of pancreatic cancer within a population-based case-control study in the Francophone community in Montreal, Canada. Int J Pancreatol. 1991 Nov-Dec; 10(3-4):183-196. [PubMed: 1787333]

13. Silverman DT. Risk factors for pancreatic cancer: a case-control study based on direct interviews. Teratog Carcinog Mutagen. 2001; 21(1):7-25. [PubMed: 11135318]

14. Coughlin SS, Calle EE, Patel AV, Thun MJ. Predictors of pancreatic cancer mortality among a large cohort of United States adults. Cancer Causes Control. 2000 Dec; 11(10):915-923. [PubMed: 11142526]

15. Hemminki K, Li X. Familial and second primary pancreatic cancers: a nationwide epidemiologic study from Sweden. Int J Cancer. 2003 Feb 10; 103(4):525-530. [PubMed: 12478670]

16. Klein AP, Beaty TH, Bailey-Wilson JE, Brune KA, Hruban RH, Petersen GM. Evidence for a major gene influencing risk of pancreatic cancer. Genet Epidemiol. 2002 Aug; 23(2):133-149. [PubMed: 12214307]

17. Pogue-Geile KL, Chen R, Bronner MP, et al. Palladin mutation causes familial pancreatic cancer and suggests a new cancer mechanism. PLoS Med. 2006 Dec.3(12):e516. [PubMed: 17194196]

18. Earl J, Yan L, Vitone LJ, et al. Evaluation of the 4q32-34 locus in European familial pancreatic cancer. Cancer Epidemiol Biomarkers Prev. 2006 Oct; 15(10):1948-1955. [PubMed: 17035404]

19. Slater E, Amrillaeva V, Fendrich V, et al. Palladin mutation causes familial pancreatic cancer: absence in European families. PLoS Med. 2007 Apr.4(4):e164. [PubMed: 17455999]

20. Klein AP, de Andrade M, Hruban RH, et al. Linkage analysis of chromosome 4 in families with familial pancreatic cancer. Cancer Biol Ther. 2007 Mar; 6(3):320-323. [PubMed: 17312386]

21. Salaria SN, Illei P, Sharma R, et al. Palladin is overexpressed in the non-neoplastic stroma of infiltrating ductal adenocarcinomas of the pancreas, but is only rarely overexpressed in neoplastic cells. Cancer Biol Ther. 2007 Mar; 6(3):324-328. [PubMed: 17404500]

22. Hahn SA, Greenhalf B, Ellis I, et al. BRCA2 germline mutations in familial pancreatic carcinoma. J Natl Cancer Inst. 2003 Feb 5; 95(3):214-221. [PubMed: 12569143]

23. Murphy KM, Brune KA, Griffin C, et al. Evaluation of candidate genes MAP2K4, MADH4, ACVR1B, and BRCA2 in familial pancreatic cancer: deleterious BRCA2 mutations in $17 \%$. Cancer Res. 2002 Jul 1; 62(13):3789-3793. [PubMed: 12097290]

24. Klein AP, Brune KA, Petersen GM, et al. Prospective risk of pancreatic cancer in familial pancreatic cancer kindreds. Cancer Res. 2004 Apr 1; 64(7):2634-2638. [PubMed: 15059921] 
25. Wang W, Chen S, Brune KA, Hruban RH, Parmigiani G, Klein AP. PancPRO: risk assessment for individuals with a family history of pancreatic cancer. J Clin Oncol. 2007 Apr 10; 25(11):14171422. [PubMed: 17416862]

26. Volikos E, Robinson J, Aittomaki K, et al. LKB1 exonic and whole gene deletions are a common cause of Peutz-Jeghers syndrome. J Med Genet. 2006 May.43(5):e18. [PubMed: 16648371]

27. Aretz S, Stienen D, Uhlhaas S, et al. High proportion of large genomic STK11 deletions in PeutzJeghers syndrome. Hum Mutat. 2005 Dec; 26(6):513-519. [PubMed: 16287113]

28. Giardiello FM, Brensinger JD, Tersmette AC, et al. Very high risk of cancer in familial PeutzJeghers syndrome. Gastroenterology. 2000; 119(6):1447-1453. [PubMed: 11113065]

29. Hearle N, Schumacher V, Menko FH, et al. Frequency and spectrum of cancers in the PeutzJeghers syndrome. Clin Cancer Res. 2006 May 15; 12(10):3209-3215. [PubMed: 16707622]

30. Haluska FG, Hodi FS. Molecular genetics of familial cutaneous melanoma. J Clin Oncol. 1998 Feb; 16(2):670-682. [PubMed: 9469357]

31. Goldstein AM, Chan M, Harland M, et al. Features associated with germline CDKN2A mutations: a GenoMEL study of melanoma-prone families from three continents. J Med Genet. 2007 Feb; 44(2):99-106. [PubMed: 16905682]

32. Soufir N, Avril MF, Chompret A, et al. Prevalence of p16 and CDK4 germline mutations in 48 melanoma-prone families in France. The French Familial Melanoma Study Group. Hum Mol Genet. 1998 Feb; 7(2):209-216. [PubMed: 9425228]

33. Kamb A, Shattuck-Eidens D, Eeles R, et al. Analysis of the p16 gene (CDKN2) as a candidate for the chromosome 9p melanoma susceptibility locus. Nat Genet. 1994 Sep; 8(1):23-26. [PubMed: 7987388]

34. Hussussian CJ, Struewing JP, Goldstein AM, et al. Germline p16 mutations in familial melanoma. Nat Genet. 1994 Sep; 8(1):15-21. [PubMed: 7987387]

35. Lynch HT, Frichot BC 3rd, Lynch JF. Familial atypical multiple mole-melanoma syndrome. J Med Genet. 1978 Oct; 15(5):352-356. [PubMed: 739524]

36. Goldstein AM, Goldin LR, Dracopoli NC, Clark WH Jr, Tucker MA. Two-locus linkage analysis of cutaneous malignant melanoma/dysplastic nevi. Am J Hum Genet. 1996 May; 58(5):10501056. [PubMed: 8651266]

37. Lynch HT, Fusaro RM, Lynch JF, Brand R. Pancreatic cancer and the FAMMM syndrome. Fam Cancer. 2008; 7(1):103-112. [PubMed: 17992582]

38. Lynch HT, Brand RE, Hogg D, et al. Phenotypic variation in eight extended CDKN2A germline mutation familial atypical multiple mole melanoma-pancreatic carcinoma-prone families: the familial atypical mole melanoma-pancreatic carcinoma syndrome. Cancer. 2002 Jan 1; 94(1):8496. [PubMed: 11815963]

39. Goldstein AM, Fraser MC, Struewing JP, et al. Increased risk of pancreatic cancer in melanomaprone kindreds with p16INK4 mutations. N Engl J Med. 1995 Oct 12; 333(15):970-974. [PubMed: 7666916]

40. Rutter JL, Bromley CM, Goldstein AM, et al. Heterogeneity of risk for melanoma and pancreatic and digestive malignancies: a melanoma case-control study. Cancer. 2004 Dec 15; 101(12):28092816. [PubMed: 15529312]

41. Lynch HT, Brand RE, Lynch JF, et al. Genetic counseling and testing for germline p16 mutations in two pancreatic cancer-prone families. Gastroenterology. 2000 Dec; 119(6):1756-1760. [PubMed: 11113097]

42. Kastrinos F, Mukherjee B, Tayob N, et al. Risk of pancreatic cancer in families with Lynch syndrome. Jama. 2009 Oct 28; 302(16):1790-1795. [PubMed: 19861671]

43. Yamamoto H, Itoh F, Nakamura H, et al. Genetic and clinical features of human pancreatic ductal adenocarcinomas with widespread microsatellite instability. Cancer Res. 2001 Apr 1; 61(7):3139_ 3144. [PubMed: 11306499]

44. Wilentz RE, Goggins M, Redston M, et al. Genetic, immunohistochemical, and clinical features of medullary carcinoma of the pancreas: A newly described and characterized entity. Am J Pathol. 2000 May; 156(5):1641-1651. [PubMed: 10793075]

45. Goggins M, Offerhaus GJ, Hilgers W, et al. Pancreatic adenocarcinomas with DNA replication errors (RER+) are associated with wild-type K-ras and characteristic histopathology. Poor 
differentiation, a syncytial growth pattern, and pushing borders suggest RER+ Am J Pathol. 1998 Jun; 152(6):1501-1507. [PubMed: 9626054]

46. Sinilnikova OM, Mazoyer S, Bonnardel C, Lynch HT, Narod SA, Lenoir GM. BRCA1 and BRCA2 mutations in breast and ovarian cancer syndrome: reflection on the Creighton University historical series of high risk families. Fam Cancer. 2006; 5(1):15-20. [PubMed: 16528604]

47. Brose MS, Rebbeck TR, Calzone KA, Stopfer JE, Nathanson KL, Weber BL. Cancer risk estimates for BRCA1 mutation carriers identified in a risk evaluation program. J Natl Cancer Inst. 2002 Sep 18; 94(18):1365-1372. [PubMed: 12237282]

48. Thompson D, Easton DF. Cancer Incidence in BRCA1 mutation carriers. J Natl Cancer Inst. 2002 Sep 18; 94(18):1358-1365. [PubMed: 12237281]

49. Skudra S, Staka A, Pukitis A, et al. Association of genetic variants with pancreatic cancer. Cancer Genet Cytogenet. 2007 Nov; 179(1):76-78. [PubMed: 17981219]

50. Breast Cancer Linkage Consortium T. Cancer Risks in BRCA2 Mutation Carriers. J. Natl. Cancer Inst. 1999; 91(15):1310-1316. [PubMed: 10433620]

51. Couch FJ, Johnson MR, Rabe KG, et al. The prevalence of BRCA2 mutations in familial pancreatic cancer. Cancer Epidemiol Biomarkers Prev. 2007 Feb; 16(2):342-346. [PubMed: 17301269]

52. Goggins M, Schutte M, Lu J, et al. Germline BRCA2 gene mutations in patients with apparently sporadic pancreatic carcinomas. Cancer Res. 1996 Dec 1; 56(23):5360-5364. [PubMed: 8968085]

53. Struewing JP, Abeliovich D, Peretz T, et al. The carrier frequency of the BRCA1 185delAG mutation is approximately 1 percent in Ashkenazi Jewish individuals. Nat Genet. 1995 Oct; 11(2): 198-200. [PubMed: 7550349]

54. Hartge P, Struewing JP, Wacholder S, Brody LC, Tucker MA. The prevalence of common BRCA1 and BRCA2 mutations among Ashkenazi Jews. Am J Hum Genet. 1999 Apr; 64(4):963-970. [PubMed: 10090881]

55. Ozcelik H, Schmocker B, Di Nicola N, et al. Germline BRCA2 6174delT mutations in Ashkenazi Jewish pancreatic cancer patients. Nat Genet. 1997 May; 16(1):17-18. [PubMed: 9140390]

56. Roa BB, Boyd AA, Volcik K, Richards CS. Ashkenazi Jewish population frequencies for common mutations in BRCA1 and BRCA2. Nat Genet. 1996 Oct; 14(2):185-187. [PubMed: 8841191]

57. Ferrone CR, Levine DA, Tang LH, et al. BRCA germline mutations in Jewish patients with pancreatic adenocarcinoma. J Clin Oncol. 2009 Jan 20; 27(3):433-438. [PubMed: 19064968]

58. Teich N, Rosendahl J, Toth M, Mossner J, Sahin-Toth M. Mutations of human cationic trypsinogen (PRSS1) and chronic pancreatitis. Hum Mutat. 2006 Aug; 27(8):721-730. [PubMed: 16791840]

59. Sahin-Toth M, Toth M. Gain-of-function mutations associated with hereditary pancreatitis enhance autoactivation of human cationic trypsinogen. Biochem Biophys Res Commun. 2000 Nov 19; 278(2):286-289. [PubMed: 11097832]

60. Teich N, Nemoda Z, Kohler H, et al. Gene conversion between functional trypsinogen genes PRSS1 and PRSS2 associated with chronic pancreatitis in a six-year-old girl. Hum Mutat. 2005 Apr; 25(4):343-347. [PubMed: 15776435]

61. Lowenfels AB, Maisonneuve P, DiMagno EP, et al. Hereditary pancreatitis and the risk of pancreatic cancer. International Hereditary Pancreatitis Study Group. J Natl Cancer Inst. 1997 Mar 19; 89(6):442-446. [PubMed: 9091646]

62. Howes N, Lerch MM, Greenhalf W, et al. Clinical and genetic characteristics of hereditary pancreatitis in Europe. Clin Gastroenterol Hepatol. 2004 Mar; 2(3):252-261. [PubMed: 15017610]

63. Lowenfels AB, Maisonneuve P, Whitcomb DC, Lerch MM, DiMagno EP. Cigarette smoking as a risk factor for pancreatic cancer in patients with hereditary pancreatitis. Jama. $2001 \mathrm{Jul} 11$; 286(2): 169-170. [PubMed: 11448279]

64. Castillo CF, Adsay NV. Intraductal Papillary Mucinous Neoplasms of the Pancreas. Gastroenterology. 2010 September.139

65. Hruban RH, Adsay NV, Albores-Saavedra J, et al. Pancreatic intraepithelial neoplasia: a new nomenclature and classification system for pancreatic duct lesions. Am J Surg Pathol. 2001 May; 25(5):579-586. [PubMed: 11342768] 
66. Hruban RH, Takaori K, Klimstra DS, et al. An illustrated consensus on the classification of pancreatic intraepithelial neoplasia and intraductal papillary mucinous neoplasms. Am J Surg Pathol. 2004 Aug; 28(8):977-987. [PubMed: 15252303]

67. Brentnall TA, Bronner MP, Byrd DR, Haggitt RC, Kimmey MB. Early diagnosis and treatment of pancreatic dysplasia in patients with a family history of pancreatic cancer. Ann Intern Med. 1999; 131(4):247-255. [PubMed: 10454945]

68. Canto MI, Goggins M, Yeo CJ, et al. Screening for pancreatic neoplasia in high-risk individuals: an EUS-based approach. Clin Gastroenterol Hepatol. 2004 Jul; 2(7):606-621. [PubMed: 15224285]

69. Canto MI, Goggins M, Hruban RH, et al. Screening for early pancreatic neoplasia in high-risk individuals: a prospective controlled study. Clin Gastroenterol Hepatol. 2006 Jun; 4(6):766-781. quiz 665. [PubMed: 16682259]

70. Steinberg WM, Barkin JS, Bradley EL 3rd, et al. Should patients with a strong family history of pancreatic cancer be screened on a periodic basis for cancer of the pancreas? Pancreas. $2009 \mathrm{Jul}$; 38(5):e137-e150. [PubMed: 19550273]

71. Greer JB, Lynch HT, Brand RE. Hereditary pancreatic cancer: a clinical perspective. Best Pract Res Clin Gastroenterol. 2009; 23(2):159-170. [PubMed: 19414143]

72. Langer P, Kann PH, Fendrich V, et al. Five years of prospective screening of high-risk individuals from families with familial pancreatic cancer. Gut. 2009 Oct; 58(10):1410-1418. [PubMed: 19470496]

73. DeWitt J, Devereaux B, Chriswell M, et al. Comparison of endoscopic ultrasonography and multidetector computed tomography for detecting and staging pancreatic cancer. Ann Intern Med. 2004 Nov 16; 141(10):753-763. [PubMed: 15545675]

74. Aithal GP, Chen RY, Cunningham JT, et al. Accuracy of EUS for detection of intraductal papillary mucinous tumor of the pancreas. Gastrointest Endosc. 2002 Nov; 56(5):701-707. [PubMed: 12397279]

75. Biankin AV, Kench JG, Biankin SA, et al. Pancreatic Intraepithelial Neoplasia in Association With Intraductal Papillary Mucinous Neoplasms of the Pancreas: Implications for Disease Progression and Recurrence. Am J Surg Pathol. 2004 Sep; 28(9):1184-1192. [PubMed: 15316318]

76. Brune K, Abe T, Canto M, et al. Multifocal neoplastic precursor lesions associated with lobular atrophy of the pancreas in patients having a strong family history of pancreatic cancer. Am J Surg Pathol. 2006 Sep; 30(9):1067-1076. [PubMed: 16931950]

77. Fukukura Y, Fujiyoshi F, Hamada H, et al. Intraductal papillary mucinous tumors of the pancreas. Comparison of helical CT and MR imaging. Acta Radiol. 2003 Sep; 44(5):464-471. [PubMed: 14510751]

78. Albert J, Schilling D, Breer H, Jungius KP, Riemann JF, Adamek HE. Mucinous cystadenomas and intraductal papillary mucinous tumors of the pancreas in magnetic resonance cholangiopancreatography. Endoscopy. 2000 Jun; 32(6):472-476. [PubMed: 10863915]

79. Fukukura Y, Fujiyoshi F, Sasaki M, Nakajo M. Pancreatic duct: morphologic evaluation with MR cholangiopancreatography after secretin stimulation. Radiology. 2002 Mar; 222(3):674-680. [PubMed: 11867784]

80. Brand RE, Lerch MM, Rubinstein WS, et al. Advances in counselling and surveillance of patients at risk for pancreatic cancer. Gut. 2007 Oct; 56(10):1460-1469. [PubMed: 17872573]

81. Rulyak SJ, Lowenfels AB, Maisonneuve P, Brentnall TA. Risk factors for the development of pancreatic cancer in familial pancreatic cancer kindreds. Gastroenterology. 2003 May; 124(5): 1292-1299. [PubMed: 12730869]

82. Harsha HC, Kandasamy K, Ranganathan P, et al. A compendium of potential biomarkers of pancreatic cancer. PLoS Med. 2009 Apr 7.6(4):e1000046. [PubMed: 19360088]

83. Vasen HF, Gruis NA, Frants RR, van Der Velden PA, Hille ET, Bergman W. Risk of developing pancreatic cancer in families with familial atypical multiple mole melanoma associated with a specific 19 deletion of p16 (p16-Leiden). Int J Cancer. 2000 Sep 15; 87(6):809-811. [PubMed: 10956390] 
84. van Asperen CJ, Brohet RM, Meijers-Heijboer EJ, et al. Cancer risks in BRCA2 families: estimates for sites other than breast and ovary. J Med Genet. 2005 Sep.42(9):711. [PubMed: 16141007] 
Table 1

Inherited Syndromes Associated With Increased Risk of Pancreatic Cancer

\begin{tabular}{|c|c|c|c|}
\hline Syndrome & Gene & Gene Function & $\begin{array}{l}\text { Lifetime Risk } \\
\text { for } \\
\text { Pancreatic } \\
\text { Cancer }(\%)\end{array}$ \\
\hline Hereditary pancreatitis ${ }^{61}$ & PRSS1 & Cationic trypsinogen & $25-40$ \\
\hline Familial atypical multiple mole melanoma ${ }^{37,83}$ & $\begin{array}{l}p 16 / \\
C D K N 2 A\end{array}$ & Tumor suppressor & $10-17$ \\
\hline Hereditary breast ovarian cancer syndrome ${ }^{47-48,84}$ & $\begin{array}{l}B R C A 2 \\
B R C A 1\end{array}$ & $\begin{array}{l}\text { Tumor suppressor } \\
\text { Tumor suppressor }\end{array}$ & $\begin{array}{l}5 \\
3.6\end{array}$ \\
\hline Peutz-Jeghers syndrome ${ }^{28}$ & $\begin{array}{l}\text { STK11/ } \\
\text { LKB1 }\end{array}$ & $\begin{array}{l}\text { Tumor suppressor, serine threonine } \\
\text { kinase }\end{array}$ & 36 \\
\hline Lynch syndrome $^{42}$ & MLH1, MSH2, MSH6, PMS2 & Mismatch repair & 3.7 \\
\hline
\end{tabular}


Table 2

Risk of Pancreatic Cancer in Familial Pancreatic Cancer Kindreds ${ }^{*} 24,70$

\begin{tabular}{|l|l|l|}
\hline $\begin{array}{l}\text { Number and type of } \\
\text { affected relatives }\end{array}$ & $\begin{array}{l}\text { Standardized Incidence } \\
\text { Ratio } \mathbf{( 9 5 \%} \mathbf{C I})\end{array}$ & Lifetime risk (\%) \\
\hline$\geq$ 3 First-degree relatives & $32(10.4-74.7)$ & 40 \\
\hline 2 First-degree relatives & $6.4(1.8-16.4)$ & $8-12$ \\
\hline 1 First-degree relative & $4.5(0.54-16.3)$ & 6.0 \\
\hline General population & 1 & 1.3 \\
\hline
\end{tabular}

* Data were derived from familial pancreatic cancer (FPC) kindreds. FPC kindreds were defined as kindreds having at least one pair of first-degree relatives with pancreatic cancer. These data do not apply to sporadic pancreatic cancer. 
Table 3

Potential Candidates for Screening for Pancreatic Cancer ${ }^{\dagger} 42,80$

An affected individual with Peutz-Jeghers syndrome
An affected individual with hereditary pancreatitis
$\geq 3$ first-, second- or third-degree relatives with pancreatic cancer, with at least one pancreatic cancer in a first-degree relative
$\begin{aligned} & \text { A known mutation carrier of a } B R C A 1^{*}, B R C A 2, p 16, M L H 1^{*}, M S H 2^{*}, M S H 6^{*}, o r P M S 2^{*} \text { mutation and at least one first- or second-degree } \\ & \text { relative with pancreatic cancer }\end{aligned}$

${ }^{\dagger}$ Screening may also be considered in individuals with 2 first-degree relatives with pancreatic cancer 80

* Data are more limited in these categories 